\title{
Performance and Emission Test of Several Blends of Waste Plastic Oil with Diesel and Ethanol on Four Stroke Twin Cylinder Diesel Engine
}

\author{
Mr Kaustav Mukherjee, Prof C.Thamotharan \\ Bharath Institute of Science and Technology, Bharath University, Selaiyur, Chennai-73, Tamil Nadu, India.
}

\begin{abstract}
Fossil fuels are non- renewable source of energy. It is difficult to predict its availability in future. It casts a shadow of uncertainty of its supply, the immediate effect of its scarcity is rising price and its adverse impact on the growing economies like India. India imports $80 \%$ of total demand of the Petroleum products. Therefore, sourcing a sustainable energy and environment friendly alternative is needed to be developed instead of using fossil fuels. Recently waste plastics are receiving renewed interest as an alternative to fossil fuel. Waste plastics are indispensable materials in the modern life and its application in the industrial field is continuously increasing. Conversion of waste plastic to energy is one of the recent trends in minimizing not only the waste disposal but also as an alternative fuel for internal combustion engine. In this paper waste plastic oil and its blends with Diesel and Ethanol is introduced as alternative fuel. I have conducted an experimental research on this alternative fuel on various operational parameters i.e. Engine Performance and emission test with blends like D100, B20, B40, B60.
\end{abstract}

Keywords: Waste Plastic oil, Diesel, Ethanol.

\section{Introduction}

With time passing by, the fossil fuel reserves are depleting at a faster rate, causing continuous increase in price of petroleum products all over the world. The high price of petroleum products is a big concern for Indian economy. India imports on an average $80 \%$ of total demand of crude oil. It is one of the main reasons of GDP expense. Therefore an alternative cheaper fuel is required to fulfil the needs of common man and at the same time it will save precious foreign exchange.

Alternative source of fuel lies in plastic. In India 56 lakh tonnes of plastics are generated each year and only $60 \%$ of it is recycled. Safe method of disposing the waste plastic has not yet been implemented here, and dumping of waste plastic underground is hazardous to the environment. But we can use it as an alternative source of fuel for gasoline and diesel. This will save the environment from hazardous effect as well as to boosting the Indian economy. Previously, many researches were done on bio Ethanol, bio-diesel, bio-gas, waste oil recycling and di-methyl ether. All of them showed encouragement results. However, the drive for search of a new source of alternative fuel, we have performed the engine performance test by using Waste Plastic oil+Diesel+Ethanol of various blends viz. B20, B40, B60. We found that the blends of Diesel \& Waste Plastic Oil \& Ethanol gives nearer values to Diesel fuel in the Kirloskar Diesel engine, without any further modification in the engine itself.

\section{Transesterification And Pyrolysis Process}

Trans esterification is the process of exchanging the organic group $\mathrm{R}^{\prime \prime}$ of an ester with the organic group $\mathrm{R}^{\prime}$ of an alcohol. These reactions are truly catalysed by the addition of an acid or base catalyst. In this process the carbonyl carbon of the starting ester $\left(\mathrm{RCOOR}^{\prime}\right)$ undergoes nucleophylic attack by the incoming alkaloid $\left(\mathrm{R}^{2} \mathrm{O}^{-}\right)$to give a tetrahedral intermediate, which either reverts to the starting material or proceed to the transesterification product $\left(\mathrm{RCOOR}^{2}\right)$.<smiles></smiles>

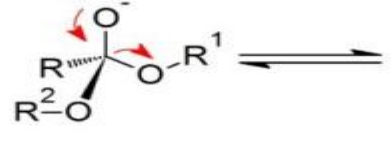<smiles>[R]C(=O)O[14CH2][O-]</smiles>

Figure 1

Nowadays, sophisticated technologies are available for plastic waste management. Pyrolysis is one such technology used to produce useful products like industrial diesel, gaseous fuel, carbon black etc. Pyrolysis is the thermal degradation of waste in oxygen starved environment in which oxygen content is low for gasification to take place. Pyrolysis liquefaction is a non-combustible heat treatment that catalytically decomposes waste material by applying heat directly or indirectly to the waste material in an oxygen free environment. It is an endothermic reaction which requires an input of energy that is typically applied indirectly through the walls of 
the reactor in which the waste material is fed into. Pyrolysis liquefaction occurs under pressure and at operating temperatures above $430^{\circ} \mathrm{C}$.

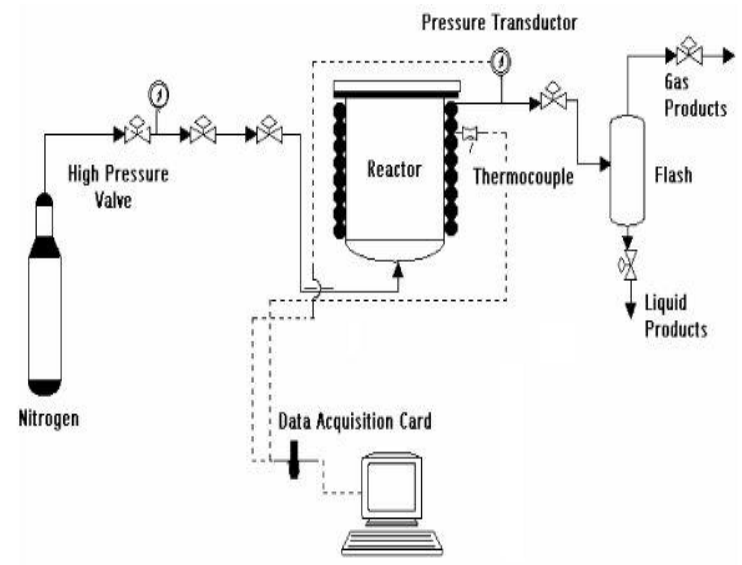

Figure 2

\section{PROPERTIES OF WATSE PLASTIC OIL AND DIESEL}

\begin{tabular}{llll}
\hline Properties & WPO & Diesel & Ethanol \\
\hline Density $\left(\mathrm{Kg} / \mathrm{m}^{2}\right)$ & 793 & 850 & 789.00 \\
\hline Pour Point $\left({ }^{\circ} \mathrm{C}\right)$ & -4 & $3-15$ & \\
Sulphur Content $(\%)$ & $<0.002$ & $<0.035$ & ------ \\
\hline Carbon residue $(\%)$ & $0.01 \% \mathrm{wt}$ & $.20 \% \mathrm{wt}$ & ------- \\
\hline Fire point $\left({ }^{\circ} \mathrm{C}\right)$ & 45 & 56 & \\
\hline Flash pont $\left({ }^{\circ} \mathrm{C}\right)$ & 40 & 50 & ------ \\
\hline Cetane number & 51 & 55 & $16.6^{0} \mathrm{C}$ \\
\hline $\begin{array}{l}\text { Kinematic viscosity } 40 \mathrm{C} \\
(\mathrm{csr})\end{array}$ & 2.149 & 3.05 & 2.00 \\
Calorific value $(\mathrm{kj} / \mathrm{Kg})$ & 41800 & 42000 & 29700 \\
\hline Ash content $(\%)$ & $<1.01$ & 0.045 & 0.02 \\
\hline
\end{tabular}

\section{Experimental Setup}

The experimental setup consists of a diesel engine and a gas analyser. The engine used in the experiment is a constant speed Kirloskar engine, four stroke twin cylinder, direct injection vertical diesel engine. The engine is water cooled. The load applied on the engine is by means of electric loading device.

The engine is mounted on concrete bed with suitable connections for water cooling and lubrication. The outlet temperature of water from engine is maintained at $50^{\circ} \mathrm{C}$ by adjusting the flow of the coolant. The schematic arrangement of experimental setup is shown in figure.

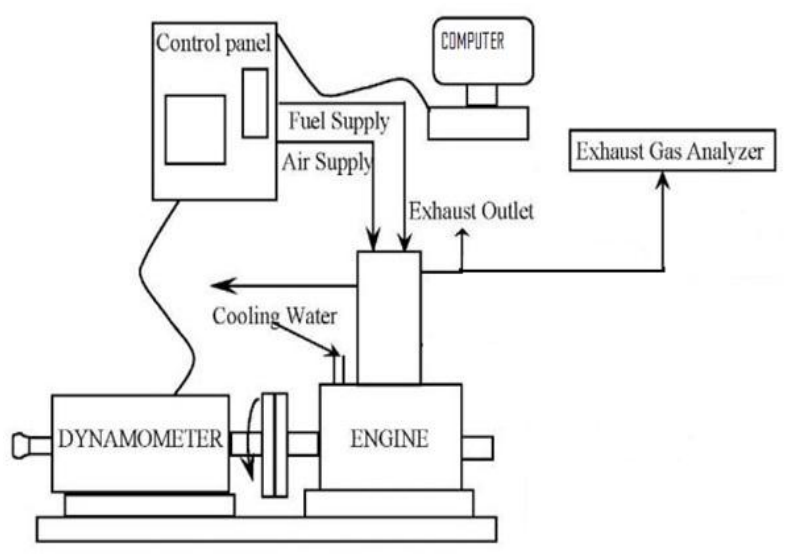

Figure 3 
1.1 Engine Specification

\begin{tabular}{ll}
\hline Engine Manufacturer & Kirloskar oil Ltd \\
\hline Bore \& Stroke & $87.5^{*} 110(\mathrm{~mm})$ \\
\hline Number of Cylinder & 2 \\
Compression Ratio & $17.5: 1$ \\
Speed & $1800 \mathrm{rpm}$ \\
Cubic Capacity & 0.661 litres \\
Method of cooling & Water cooled \\
Fuel timing & $27^{\circ}$ by spill (btde) \\
Clearance volume & $37.8 \mathrm{cc}$ \\
Rated power & $8 \mathrm{hp}$ \\
Nozzle opening pressure & $200 \mathrm{bars}$ \\
\hline
\end{tabular}

\section{Result And Discussion}

The comparison of performance and emission characteristics of CI engine using Waste Plastic Oil with Diesel and Ethanol blends is charted. The graphs are plotted for the following characteristics.

- Load Vs. Mfc

- Load Vs. Sfc

- Load Vs. B ${ }^{\text {th }} x$

- Load Vs. NOx

- Load Vs. CO

\subsection{Load Vs. Mfc}

The mass fuel consumption of biodiesel is marginally higher than that of Diesel.Diesel has slight better fuel efficiency. The graph shows that B20 values are very close to that of diesel.

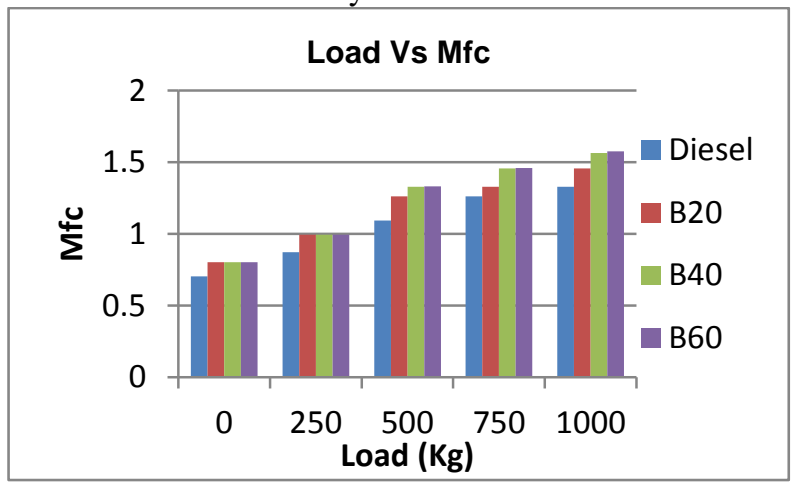

1.3 Load Vs. Sfc

Figure 4

The specific fuel consumption for diesel is lower than other bio diesel blends. Hence the fuel efficiency of diesel is slightly better than biodiesel blends. But B20 is very close to Diesel.

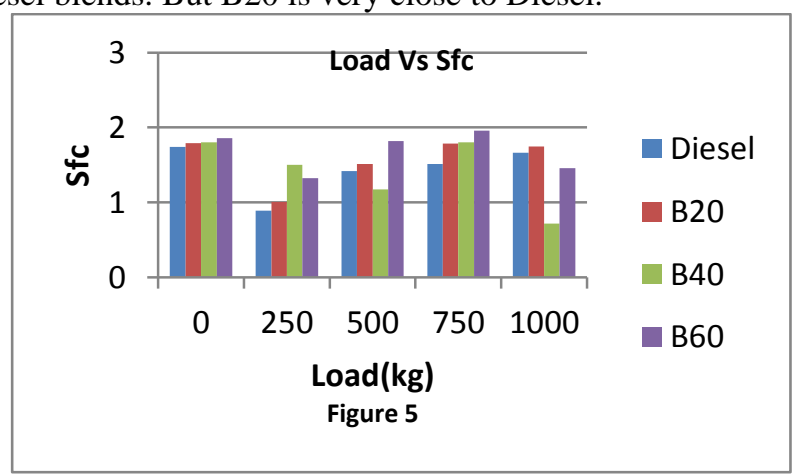

\subsection{Load Vs. Brake Thermal Efficiency}

Diesel shows a better brake thermal efficiency than biodiesel blends. But B20 values are very close to that of Diesel. 


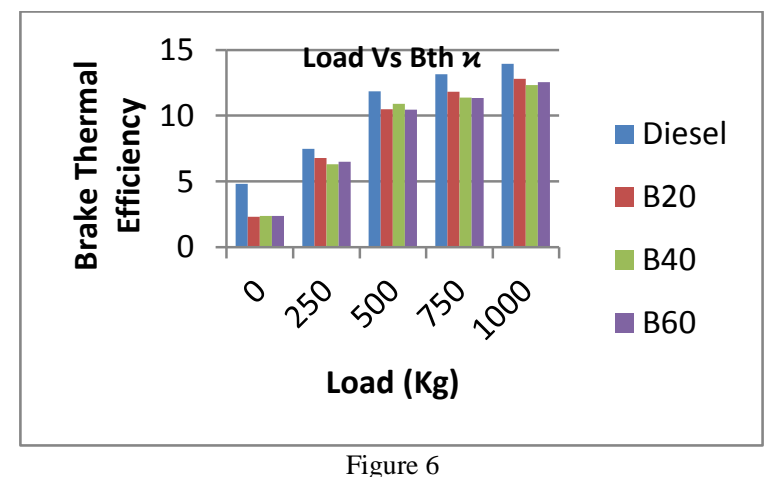

\section{Emission Characterstics}

The emissions of Internal Combustion Engine are a major concern to air pollution. The regulated pollutants are Carbon Mono-oxide (CO),Mono-Nitrogen Oxides(NOx) and unburned fuel or partly oxidised Hydro Carbons.

\subsection{Mono Nitrogen Oxides (NOx)}

As per experimental study of WPO \& Diesel \& Ethanol blends in CI engine, it indicates that the concentration of NOx varies from $0.26 \mathrm{~g} / \mathrm{km}$ at low load to $0.41 \mathrm{~g} / \mathrm{km}$ at full load for Diesel fuel. For B20 it varies from $0.26 \mathrm{~g} / \mathrm{km}$ at low load to $0.40 \mathrm{~g} / \mathrm{km}$ at full load. For B 40 it varies from $0.27 \mathrm{~g} / \mathrm{km}$ at low load to $0.39 \mathrm{~g} / \mathrm{km}$ at full load. For B60 it varies from $0.25 \mathrm{~g} / \mathrm{km}$ at low load to $0.41 \mathrm{~g} / \mathrm{km}$ at full load. Because of high heat release the NOx content increases at full load because of higher aromatic content fuel with ring structure.

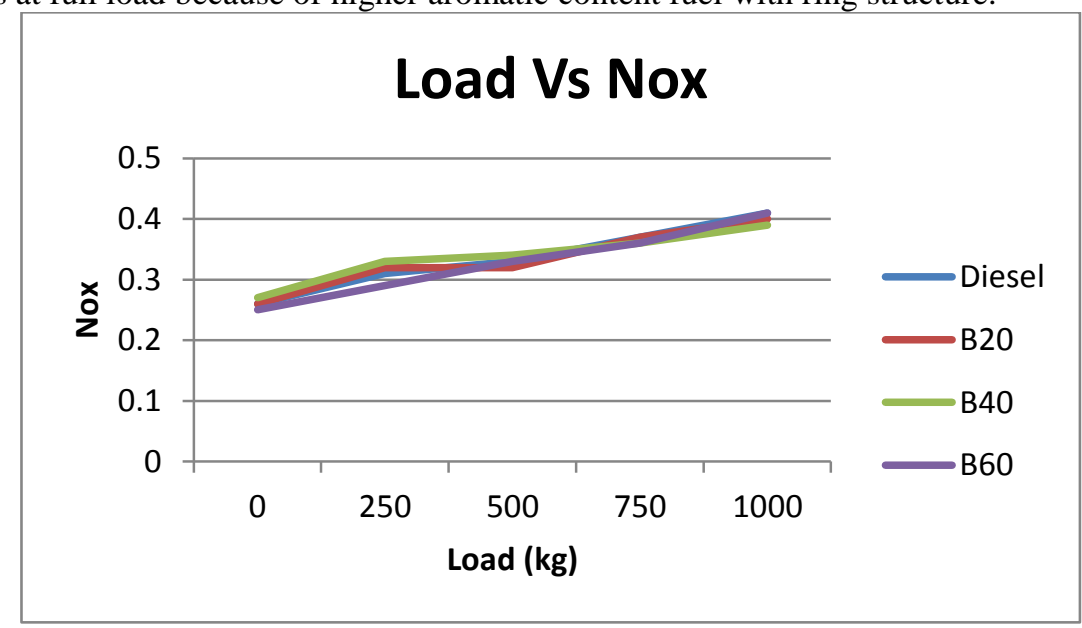

Figure 7

\subsection{Carbon mono-oxide (CO)}

Nowadays the CI engines operate with lean mixtures and hence the Co emission is low. $\mathrm{CO}$ is toxic in nature and must be controlled. The concentration of $\mathrm{CO}$ varies from $0.51 \mathrm{~g} / \mathrm{km}$ to $0.71 \mathrm{~g} / \mathrm{km}$ at low load to full load for Diesel fuel. For B20 it varies from $0.52 \mathrm{~g} / \mathrm{km}$ to $0.69 \mathrm{~g} / \mathrm{km}$ at low load to full load. For B40 it varies from $0.51 \mathrm{~g} / \mathrm{km}$ to $0.70 \mathrm{~g} / \mathrm{km}$ at low to full load. For B 60 it shows $0.52 \mathrm{~g} / \mathrm{km}$ to $0.69 \mathrm{~g} / \mathrm{km}$ at low to full load. From the above experiment it is concluded that the emission of WPO biodiesel is well under control and it is similar to that of Diesel. 


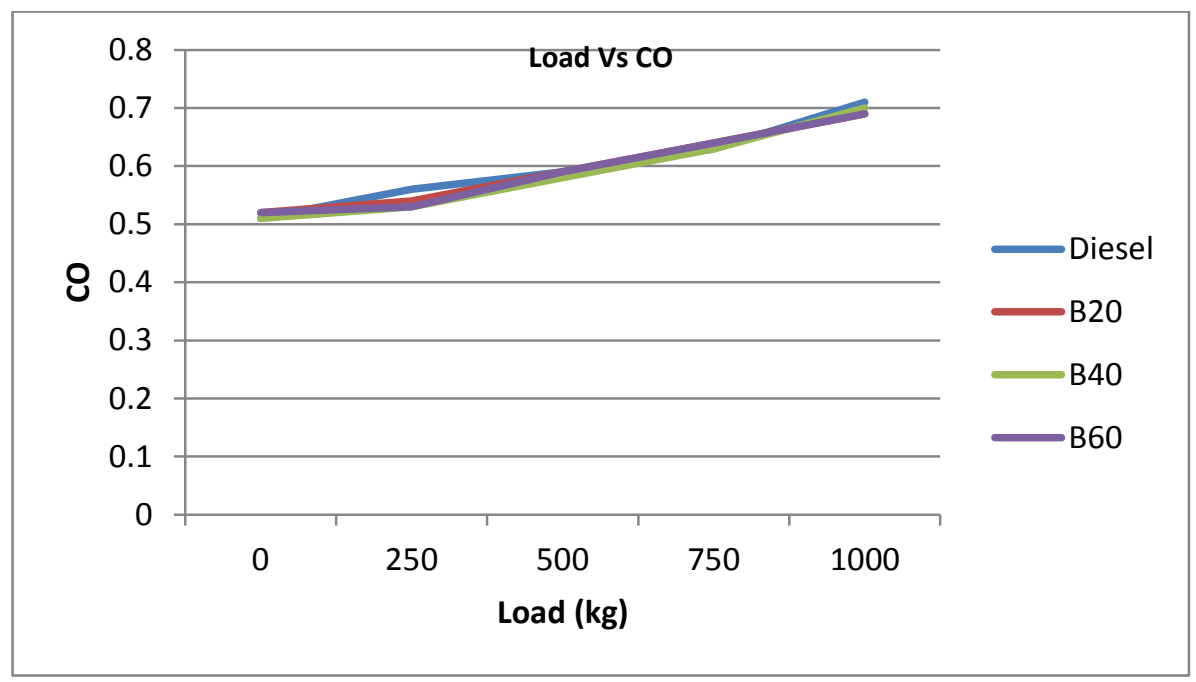

Figure 8

\section{Conclusion}

After conducting the experiment on Waste Plastic Oil with Diesel \& Ethanol it is concluded that the WPO blends represent a fairly good alternative fuel for Diesel. As the natural resources are depleting fast, WPO blend of oil can be used in future for vehicular movement. Further, it is concluded that B20 has characteristics as near to diesel. The emissions are very near to that of Diesel. It indicates that WPO oil is not at all hazardous to environment. It can be considered as neat as gasoline and diesel. If Government of India provides some subsidy for production of this bio diesel, then it will attract investment in its production. The low cost of this fuel will drive up the economy at a faster rate in one hand and at the same time it will reduce the dependence on importation of diesel/petrol oil. Generation of employment in producing bio diesel and assuring clean environment will be an added advantage.

\section{NOMENCLATURE}

\begin{tabular}{|l|l|}
\hline $\mathrm{CI}$ & Compression Ignition \\
\hline $\mathrm{CO}$ & Carbon Mono-oxide \\
\hline $\mathrm{Co}_{2}$ & Carbon di-oxide \\
\hline $\mathrm{NOx}$ & Mono nitrogen Oxides \\
\hline $\mathrm{WPO}$ & Waste Plastic Oil \\
\hline $\mathrm{Sfc}$ & Specific fuel consumption \\
\hline $\mathrm{Mfc}$ & Mass fuel consumption \\
\hline
\end{tabular}

\section{References}

[1] Heywood JB, "Internal Combustion engine fundamentals", McGraw Hill Publication, http://www.mcgraw-hill.com (1988).

[2] Williams PT and Williams EA, "Interaction of Plastics in mixed plastic pyrolysis", Journal of Energy and fuels, 13 188-196 (1990).

[3] Walendzienwski Jerzy, "Engine fuel derived from waste plastics by thermal treatment", Journal of Fuel, 81 473-481 (2002).

[4] S.Murugan, M C Ramaswamy and G Nagrajan, "Assessment of Pyrolysis oil as an energy source for Diesel engines". Anna University, Chennai, India.

[5] Sutton D, Rush M and Richard P, "Diesel Engine Performance and Emission using different fuel/ additives combustion", SAE Technical Paper 880635, (1988).

[6] Bertolic, Del Glacomo N, "Diesel combustion improvements by the use of oxygenated synthetic fuels", SAE Paper No 972972.

[7] R D Mishra, M S Murthy, "Performance emission and combustion evaluation of soapnut oil diesel blends in a compression ignition engine". Mechanical Engineering Department, NIT, Silchar, India, (2011).

[8] http://www.pcd.go.th/info_serv/waste_wastethai.htm. "Waste plastic in Thailand", Pollution control department, Thailand.

[9] Agarwal Avinash Kumar, "Biofuel application as fuel internal combustion engines", Journal of energy and combustion Science, 33 233-77 (2007).

[10] V ganeshan, "Internal Combustion Engines", (2004).

[11] Alan C Hasen, Qin Zhang, Peter WL Lyne, "Ethanol Diesel fuel blend" University of Illionis, (2004). 